\title{
Role of HOXA7 to HOXAI 3 and PBXI genes in various forms of MRKH syndrome (congenital absence of uterus and vagina)
} Agnès Burel ${ }^{1}$, Thomas Mouchel ${ }^{2}$, Sylvie Odent ${ }^{3}$, Filiz Tiker ${ }^{4}$,
Bertrand Knebelmann ${ }^{5}$, Isabelle Pellerin ${ }^{1}$ and Daniel Guerrier*1

Address: ${ }^{1}$ CNRS UMR 6061, Génétique et Développement, Université de Rennes 1, Groupe IPD, IFR140 GFAS, Faculté de Médecine, Rennes, France, 2 Service de Gynécologie Obstétrique, CHU de Rennes, Rennes, France, ${ }^{3}$ Unité de Génétique Médicale, Hôpital Sud, Rennes, France, ${ }^{4}$ Department of Pediatrics, Baskent University, Adana Hospital, Adana, Turkey and ${ }^{5}$ Service de Néphrologie, Hôpital Necker-Enfants-Malades, Paris, France

Email: Agnès Burel - agnes.burel@univ-rennes1.fr; Thomas Mouchel - thomas.mouchel@club-internet.fr; Sylvie Odent - sylvie.odent@churennes.fr; Filiz Tiker - filiztiker@yahoo.com; Bertrand Knebelmann - knebelmann@necker.fr; Isabelle Pellerin - isabelle.pellerin@univrennes1.fr; Daniel Guerrier* - daniel.guerrier@univ-rennes1.fr

* Corresponding author

Published: 23 March 2006

Journal of Negative Results in BioMedicine2006, 5:4 doi:10.1 I86/1477-575 I-5-4

This article is available from: http://www.jnrbm.com/content/5/l/4

(C) 2006Burel et al; licensee BioMed Central Ltd.

This is an Open Access article distributed under the terms of the Creative Commons Attribution License (http://creativecommons.org/licenses/by/2.0), which permits unrestricted use, distribution, and reproduction in any medium, provided the original work is properly cited.

\begin{abstract}
The Mayer-Rokitansky-Küster-Hauser (MRKH) syndrome refers to the congenital absence or severe hypoplasia of the female genital tract, often described as uterovaginal aplasia which is the prime feature of the syndrome. It is the second cause of primary amenorrhea after gonadal dysgenesis and occurs in $\sim 1$ in 4500 women. Aetiology of this syndrome remains poorly understood. Frequent association of other malformations with the MRKH syndrome, involving kidneys, skeleton and ears, suggests the involvement of major developmental genes such as those of the HOX family. Indeed mammalian HOX genes are well known for their crucial role during embryogenesis, particularly in axial skeleton, hindbrain and limb development. More recently, their involvement in organogenesis has been demonstrated notably during urogenital differentiation. Although null mutations of HOX genes in animal models do not lead to MRKH-like phenotypes, dominant mutations in their coding sequences or aberrant expression due to mutated regulatory regions could well account for it. Sequence analysis of coding regions of HOX candidate genes and of PBXI, a likely HOX cofactor during Müllerian duct differentiation and kidney morphogenesis, did not reveal any mutation in patients showing various forms of MRKH syndrome. This tends to show that HOX genes are not involved in MRKH syndrome. However it does not exclude that other mechanisms leading to HOX dysfunction may account for the syndrome.
\end{abstract}

\section{Background}

The most common cause of vaginal agenesis is congenital absence of the uterus and vagina which is also referred to as Müllerian aplasia, Müllerian agenesis or Mayer-Rokitansky-Küster-Hauser (MRKH) syndrome [1]. The frequency of this syndrome is not yet entirely clear, although reported incidences vary from 1 in 4,000 to 5,000 female births [1-3]. Affected individuals are clearly phenotypic females with normally developed ovaries $[4,5]$ and normal 46, XX karyotype [6,7]. Aetiology of the syndrome is poorly understood but it is often associated with other anomalies including renal defects, skeletal abnormalities and deafness (MURCS association [8]), suggesting the 
involvement of major developmental genes such as HOX genes [9-12].

The homeobox (HOX) genes belong to a large family of 39 genes organized in four clusters, HOXA, HOXB, HOXC and HOXD, each on a different chromosome. During organogenesis, the proteins encoded by these genes act through various and highly complex spatiotemporal combinations to trigger positional identity of embryonic cells. This determines the patterning and segment identity along the anterior-posterior axis of the skeleton and a variety of organ systems [13]. For instance, 30 HOX proteins participate to the elaboration of the spine, 12 for the digestive tract and 7 for the urogenital tract [14]. More precisely, Müllerian ducts (the primordia for oviducts, uterus, cervix and anterior vagina) development seems to involve relatively few HOX genes in the mouse model. Indeed, HOXA7 [15], HOXA9 to HOXA13 [16], as well as HOXD9 to HOXD13 [17], are expressed along the differentiating Müllerian duct. However, alteration of the female genital tract is only observed in HOXA10, -A11 and -A13 deficient mice (homozygotic inactivation of the gene): - in HOXA10 -/- mice, the upper part of the uterus is transformed into oviduct, the uterotubular junction is abnormal as well as the uterine epithelium and an anterior homeotic transformation of lumbar vertebrae has occurred [18]; - in HOXA11 -/- mice, the uterus is thinner and shorter than normal and endometrial glands have not developed [19]; in HOXA13 -/- mice, the distal Müllerian duct has not developed [20]. Finally HOXA10 to HOXA13 are also expressed in the developing kidney [21] and are both required for correct patterning of the skeleton [22].

HOX proteins share in common a highly conserved 60 amino acid DNA binding motif referred to as the homeodomain. Proteins containing this domain are regulatory factors that control expression of target genes [23]. Their high biological specificity comes from cooperation with specific cofactors that contribute to modulate DNA binding specificity. Members of the three amino-acid loop extension (TALE) class of homeodomain proteins that comprise the mammalian PBX proteins [24] and the MEIS-like TALE factors or MEINOX group (mammalian MEIS and PREP1 proteins) [25] are now considered as essential cofactors forming heterotrimeric complexes with HOX proteins that regulate specific target gene transcription [26]. Among these cofactors, PBX1 is of great interest in regards to malformations found in MRKH syndrome: it

Table I: Forward (F) and reverse (R) primers used for PCR-mediated amplification of genomic DNA of HOXA7 to HOXAI3 genes exons.

\begin{tabular}{|c|c|c|c|}
\hline Primer name & Gene segment & Sequence 5'-3' & Product size (bp) \\
\hline $\begin{array}{l}\text { HOXA 7-I-F } \\
\text { HOXA 7-I-R }\end{array}$ & HOXA-7 exon I & $\begin{array}{l}\text { TTGGTGTAAATCTGGGGGTG } \\
\text { TTAAAACCAGAAAGGCTGCG }\end{array}$ & 637 \\
\hline $\begin{array}{l}\text { HOXA 7-2-F } \\
\text { HOXA 7-2-R }\end{array}$ & HOXA-7 exon 2 & $\begin{array}{l}\text { GACTAGGCCAGGAGGAAGGT } \\
\text { GGGAGCTGGAGTAGGTGATG }\end{array}$ & 697 \\
\hline $\begin{array}{l}\text { HOXA 9-Ia-F } \\
\text { HOXA 9-Ia-R }\end{array}$ & HOXA-9 exon I (first half) & $\begin{array}{l}\text { TGCCACCAAGTTGTTACATGA } \\
\text { CAGCGGTTCAGGTTTAATGC }\end{array}$ & 492 \\
\hline $\begin{array}{l}\text { HOXA 9-Ib-F } \\
\text { HOXA 9-Ib-R }\end{array}$ & HOXA-9 exon I (second half) & $\begin{array}{l}\text { GCAGGTACATGCGCTCCT } \\
\text { AAGGCAGGCTCGAGAGAAAC }\end{array}$ & 356 \\
\hline $\begin{array}{l}\text { HOXA 9-2-F } \\
\text { HOXA 9-2-R }\end{array}$ & HOXA-9 exon 2 & $\begin{array}{l}\text { TGTGCGTCTTCTGCTCCTAA } \\
\text { CGGACAGTTCTTTCTTTTTCTCTC }\end{array}$ & 343 \\
\hline $\begin{array}{l}\text { HOXA I0-la-F } \\
\text { HOXA I0-Ia-R }\end{array}$ & HOXA- 10 exon I (first half) & $\begin{array}{l}\text { CTCCTGGCCCATCAATACAG } \\
\text { GAGACTTTGGGGCATTTGTC }\end{array}$ & 728 \\
\hline $\begin{array}{l}\text { HOXA I0-Ib-F } \\
\text { HOXA I0-Ib-R }\end{array}$ & HOXA-I0 exon I (second half) & $\begin{array}{l}\text { GCGCAGAACATCAAAGAAGA } \\
\text { TCCTTGTGTCTGCCTGTCTG }\end{array}$ & 535 \\
\hline $\begin{array}{l}\text { HOXA } 10-2-F \\
\text { HOXA } 10-2-R\end{array}$ & HOXA- 10 exon 2 & $\begin{array}{l}\text { TGGCCTCGACTTAATCATCC } \\
\text { AGACAGAGGGAGGGGACCAG }\end{array}$ & 378 \\
\hline $\begin{array}{l}\text { HOXA II-Ia-F } \\
\text { HOXA II-Ia-R }\end{array}$ & HOXA-II exon I (first half) & $\begin{array}{l}\text { CAGCTGCAGTGGAGAATCAT } \\
\text { CTTCTCGGCGCTCTTGTC }\end{array}$ & 562 \\
\hline $\begin{array}{l}\text { HOXA II-Ib-F } \\
\text { HOXA II-Ib-R }\end{array}$ & HOXA-II exon I (second half) & $\begin{array}{l}\text { TTTTTCGAGACAGCCTACGG } \\
\text { TGCGCTAGATTTCCAACTCC }\end{array}$ & 340 \\
\hline $\begin{array}{l}\text { HOXA II-2-F } \\
\text { HOXA II-2-R }\end{array}$ & HOXA-II exon 2 & $\begin{array}{l}\text { CTCACCCCATGCCTTTTCT } \\
\text { GTCAAGGGCAAAATCTGCAT }\end{array}$ & 331 \\
\hline $\begin{array}{l}\text { HOXA I3-la-F } \\
\text { HOXA I3-la-R }\end{array}$ & HOXA-I 3 exon I (first half) & $\begin{array}{l}\text { ACTGGGGTCTTCTCCATGC } \\
\text { TGGTGGTAGAAGGCGAACTC }\end{array}$ & 727 \\
\hline $\begin{array}{l}\text { HOXA I3-Ib-F } \\
\text { HOXA I3-Ib-R }\end{array}$ & HOXA-I 3 exon I (second half) & $\begin{array}{l}\text { CAACGCCATCAAGTCGTG } \\
\text { AAGACCAGGGCTGGGAATAG }\end{array}$ & 389 \\
\hline $\begin{array}{l}\text { HOXA I3-2-F } \\
\text { HOXA I3-2-R }\end{array}$ & HOXA- 13 exon 2 & $\begin{array}{l}\text { CCGATCCCTGTGTAACTTGC } \\
\text { ATTATCTGGGCAAAGCAACG }\end{array}$ & 331 \\
\hline
\end{tabular}


Table 2: Forward (F) and reverse (R) primers used for PCR-mediated amplification of genomic DNA of PBXI gene exons.

\begin{tabular}{|c|c|c|c|}
\hline Primer name & Gene segment & Sequence 5'-3' & Product size (bp) \\
\hline $\begin{array}{l}\text { PBXI-I-F } \\
\text { PBXI-I-R }\end{array}$ & PBXI exon I & $\begin{array}{l}\text { TTTCCCCCTTCCCTGTTTAT } \\
\text { GTGATTCGGTTCCCATTGTT }\end{array}$ & 334 \\
\hline $\begin{array}{l}\text { PBXI-2-F } \\
\text { PBXI-2-R }\end{array}$ & PBXI exon 2 & $\begin{array}{l}\text { CAAATGTTTTCACCCTGTGC } \\
\text { TTTGTGACTGCTGGTTAAGTGA }\end{array}$ & 223 \\
\hline $\begin{array}{l}\text { PBXI-3-F } \\
\text { PBXI-3-R }\end{array}$ & PBXI exon 3 & $\begin{array}{l}\text { TGGCAGCTTATGTAGCCAAA } \\
\text { GTTGTGCTTCCTCCACCCT }\end{array}$ & 404 \\
\hline $\begin{array}{l}\text { PBXI-4-F } \\
\text { PBXI-4-R }\end{array}$ & PBXI exon 4 & $\begin{array}{l}\text { GCCCACGTGGCCTAATGTCATA } \\
\text { TGGGGTGAAACTAGAGCCTG }\end{array}$ & 372 \\
\hline $\begin{array}{l}\text { PBXI-5-F } \\
\text { PBXI-5-R }\end{array}$ & PBXI exon 5 & $\begin{array}{l}\text { TGCTCCAAATTCACCTTTTG } \\
\text { AAGACCTCTAAGAGCCTGCC }\end{array}$ & 331 \\
\hline $\begin{array}{l}\text { PBXI-6-F } \\
\text { PBXI-6-R }\end{array}$ & PBXI exon 6 & $\begin{array}{l}\text { TTCACCTCTCCCATAAAGCC } \\
\text { CCCAATGTAGGAACAGCCAG }\end{array}$ & 324 \\
\hline $\begin{array}{l}\text { PBXI-7-F } \\
\text { PBXI-7-R }\end{array}$ & PBXI exon 7 & $\begin{array}{l}\text { GGTTGCTTTGCATGTCATTC } \\
\text { TCTTGATTTTGGTTCGGTCG }\end{array}$ & 354 \\
\hline $\begin{array}{l}\text { PBXI-8-F } \\
\text { PBXI-8-R }\end{array}$ & PBXI exon 8 & $\begin{array}{l}\text { TCTGCCTCCCTTTTCCTACA } \\
\text { GATGGCATGACCGATACAGA }\end{array}$ & 304 \\
\hline $\begin{array}{l}\text { PBXI-9-F } \\
\text { PBXI-9-R }\end{array}$ & PBXI exon 9 & $\begin{array}{l}\text { AAACAGCCACCCAATCTCAG } \\
\text { TGTTTGCTGATTGCTTCGAC }\end{array}$ & 261 \\
\hline
\end{tabular}

is required for skeletal development and patterning [27], kidney morphogenesis [28] and especially, its gene inactivation leads to absence of Müllerian structures [29]. Interestingly, PBX1 is expressed in the Müllerian ducts at the onset of genital tract differentiation whereas it is absent of Wolffian ducts (the primordia for male inner genital tract) during the same period and in both sexes [30].

These overall data led us to investigate HOXA7, -A9, -A10, -A11 and -A13 genes, as well as PBX1, in several MRKH patients showing a wide range of malformations, from isolated uterovaginal aplasia to severe MURCS association. However null mutations of these genes do not result in MRKH-like phenotype in the mouse model. This is why we decided to search for simple or discrete mutations within their coding and splicing sequences. Indeed, dominant or loss-of-function mutations can impair ability of the corresponding proteins to fulfil their biological role as already showed for HOXD13 [31,32].

\section{Case reports Patient I}

This patient was initially evaluated for a vesicoureteric reflux that required surgical treatment during which a small left kidney and a partial uterine agenesis with rudimentary left horn were noticed. This was confirmed latter by laparoscopy when she was 13 year old. Additional examination revealed several skeletal abnormalities: coxa valga, unequal leg length, flexus adductus as well as L4 vertebra and sacrum malformation. At 18 year of age, laparoscopic-assisted Vechietti procedure [33] was performed. Finally her karyotype was normal.

\section{Patient 2}

This 25-year-old white woman was initially evaluated for proteinuria. Examination revealed a right single pelvic kidney and uterovaginal agenesis. She had normal sexual secondary development. Kidney biopsy showed focal and segmental hyalinosis. Spine radiograms were normal. Her karyotype was normal. At 26, she was treated by sigmoid colpoplasty [34]. During surgery, uterovaginal agenesis was confirmed with small rudimentary uterine horns.

\section{Patient 3}

This 20-year-old white woman was evaluated for primary amenorrhea. She had normal secondary sexual development. There was no cyclic abdominal pain. Family history was unremarkable. The MRKH diagnosis was confirmed by laparoscopy. Absence of right ovary and fallopian tube was noticed during surgery. However, ultrasound examination showed normal kidneys.

\section{Patients 4 to 6}

These patients are three Turkish sisters already described [35] (patients III2, III3, III5 of pedigree). Interestingly, in this family, the fourth sister (III4) was not affected but two paternal aunts (II6 and II7), among 8 siblings, were sterile and were told they had no uterus. This three sisters case corresponds to typical MRKH syndrome with primary amenorrhea, normal sexual secondary development and absence of the vagina at physical evaluation. The Müllerian agenesis was confirmed by ultrasound examination and magnetic resonance imaging of pelvis. Their karyotypes were normal. Intravenous pyelogram and spine radiograms were normal in each case. 


\section{PCR Amplification and sequencing}

Total genomic DNA was prepared from peripheral blood leukocytes according to standard procedures [36]. Local ethical review and consenting procedures were followed. PCR primers were designed to amplify HOXA7, HOXA9, HOXA10, HOXA11, HOXA13 (Table 1) and PBX1 coding exons (Table 2). PCR reactions were carried out in $25 \mu \mathrm{l}$ containing $500 \mathrm{ng}$ genomic DNA, PCR buffer $(50 \mathrm{mM}$ $\mathrm{KCl}, 10 \mathrm{mM}$ Tris $\mathrm{HCl}, \mathrm{pH}$ 9.0), $1.5 \mathrm{mM} \mathrm{MgCl} 2,0.2 \mathrm{mM}$ $\mathrm{dNTP}, 10 \mathrm{pmol}$ of each primer, and $2.5 \mathrm{U}$ Taq polymerase (Promega). PCR amplification was carried out using the "touchdown" methodology, with an initial denaturation step at $96^{\circ} \mathrm{C}$ for $3 \mathrm{~min}$. followed by 19 touchdown cycles of $45 \mathrm{~s}$ at $96^{\circ} \mathrm{C}, 45 \mathrm{~s}$ at an initial melting temperature (Tm) of $69^{\circ} \mathrm{C}$ (with a $1^{\circ} \mathrm{C}$ Tm decrease by each cycle), and $60 \mathrm{~s}$ at $72^{\circ} \mathrm{C}$. Amplification was then achieved by 11 cycles of $45 \mathrm{~s}$ at $96^{\circ} \mathrm{C}, 45 \mathrm{~s}$ at $50^{\circ} \mathrm{C}$, and $60 \mathrm{~s}$ at $72^{\circ} \mathrm{C}$, with a final extension at $72^{\circ} \mathrm{C}$ for $10 \mathrm{~min}$. For the $\mathrm{N}$-terminal exon 1 of HOXA13 gene, DMSO (5\%) was added to PCR mix. $6 \mu$ PCR product previously controlled on a $2 \%$ agarose gel, was incubated with 5 units of exonuclease I (Amersham Biosciences) and 1 unit of shrimp alkaline phosphatase (Amersham Pharmacia) in order to digest remaining primers and to inactivate unincorporated nucleotides. The enzymatic reaction was stopped by a step at $90^{\circ} \mathrm{C}$ for $15 \mathrm{~min}$. Bidirectional sequencing of the PCR products was achieved using the BigDye Terminator chemistry (PE Applied Biosystems) and each of exon-specific primers. Electrophoresis and analysis were performed on an ABI Prism 377 (PE Applied Biosystems). Sequences were analyzed and compared with sequences downloaded from GenBank by DNAStar software (DNAStar).

\section{Results and discussion}

The pattern of malformations observed in MRKH patients was, in our hypothesis, in favour of a HOX gene dysfunction. However no mutation as well as length/nucleotide polymorphism was found in the coding sequences of HOXA7 to -A13 genes of the patients we investigated. This probably refutes the hypothesis of dominant or loss-offunction mutations like those found in HOXD13 [31,32] and seems to show that quality of the corresponding proteins, if correctly expressed, can not be incriminated. Interestingly, reduced quantity of HOXA proteins (haploinsufficiency of the entire HOXA gene cluster) does not cause any of the major malformations observed in MRKH syndrome but leads to other congenital anomalies [37]. Nevertheless, other mechanisms can be suggested, such as upstream misregulation of some genes of the HOXA cluster, post-transcriptional anomalies, HOX partners' deficiency or defaults in HOX-target genes, all potentially leading to HOX-like phenotypes.

HOX genes clusters undergo very complex transcriptional controls during development, including general switch such as retinoic acid induction [38], FGFs [39,40] or Wnt [41] signalling, self-regulatory loops, specific induction or repression of HOX genes within the same cluster [42-44], as well as post-transcriptional regulations $[45,46]$. Although large-scale developmental signals deficiency would probably not account for restricted and non lethal malformations such as those observed for the MRKH syndrome, HOX misregulation due to mutations/deletions outside the coding regions could do it as already described in the HOXD gene cluster [47] and in HOXA13 gene promoter [48]. Some few regulatory regions have been characterized in the HOXA gene cluster among which, the socalled HCR (Human Control Region) [49] lying next to HOXA7, a gene somehow involved in Müllerian differentiation [15]. This 1.1 kb DNA sequence, as well as its conserved mouse equivalent, has been shown to set the anterior boundary of HOXA7 expression [49] and therefore putative other HOXA genes of the same cluster. Southern-blot experiments aiming at detecting length polymorphism such as deletion or duplication in the [HCRHOXA7] area did not reveal any major genetic event in any of the patients investigated (results not shown). This however does not imply that other regulatory regions still uncharacterized in the HOXA cluster, may not be involved in the MRKH syndrome.

Post-transcriptional regulations also take place in the overall mechanisms of HOX gene expression and participate to the elaboration of the code referred to as "combinatorial HOX code". In this way, normal and alternative splicing of HOX pre-messengers $[45,46]$ often results in two isoforms that putatively can antagonize each other [50,51]. In our experimental approach, we designed PCR/ sequencing primers so that we were able to verify the correct splicing acceptor and donor sites sequences of all exons for every gene investigated (including PBX1). No mutation was found in these sites.

PBX1 is one of the HOX genes' partners the most likely to be involved in the MRKH syndrome. Heterozygotic (+/-) inactivation of this gene does not provoke any congenital malformation in the mouse model whereas homozygotic (-/-) mice embryos die before birth due to multiple and severe malformations [27]. Therefore haploinsufficiency will probably not cause MRKH phenotype although mono-allelic mutations in a coding region of the gene may well lead to a dominant and deleterious effect such as titrating of HOX proteins clustered in non functional complexes. We carefully sequenced the overall exons of PBX1 in every patient and did not observe any mutation.

\section{Conclusion}

Investigation of candidate genes in biomedical research has often been unsuccessful unless target genes were obvious (for instance, see [52-54]). HOX genes, which play 
numerous roles during development, were good candidates for MRKH syndrome, based on deduction from their expression pattern during mouse development and from the phenotype of mice with a targeted disruption or overexpression of a specific HOX gene. Similar hypotheses were assumed for others congenital malformations or syndromes and revealed the involvement of these genes $[55,56]$. We based the present work on the investigation of MRKH patients showing various malformations associated with uterovaginal aplasia. This choice was based on the probable multigenic origins of the syndrome, assuming that at least one case would lead to evidence mutation of either a coding sequence of a HOX gene or part of the HOXA cluster (HOXA7 to -A13). Amongst the various MRKH cases analysed, we did not find any mutation in the coding sequences or in the [HCR-HOXA7] region. However, we did not sequence the whole HOXA cluster in every patient as this would have been a tremendous work but rather targeted genomic regions (coding sequences, splicing sites, regulatory sequences). Our negative results therefore do not mean that HOX genes are not involved in the syndrome. Additional investigation is necessary to settle or not the HOX hypothesis. This requires performing genetic linkage analysis of familial cases and wholegenome scan to seek for candidate chromosomal loci.

\section{Authors' contributions}

- AB was in charge of most of the PCR and sequencing reactions

- TM co-initiated this program and delineated MRKH syndromes in patients 1 and 3

- SO contributed to the diagnosis and was in charge of medical genetics

- FT provided biological samples of patients 4-6

- BK provided biological samples of patient 2

- IP created a new research group focused on molecular events triggering normal and pathological differentiation of the Müllerian ducts. She therefore offered the opportunity to DG to set up a proper clinical research program aiming at understanding the genetics of MRKH syndrome.

- DG initiated the study in IP's group and has been leading this research program since then.

\section{Acknowledgements}

We are indebted to Céline Hamon for genomic DNA purification and to Stéphane Dréano for technical help in running the automatic sequencing apparatus. DG is very grateful to Dr. Mehdi Alizadeh for helpful advice in genetics. This work was supported by the CNRS and by grants from Rennes Métropole, Conseil Régional de Bretagne and La Fondation Langlois.

\section{References}

I. Griffin JE, Edwards C, Madden JD, Harrod MJ, Wilson JD: Congenital absence of the vagina. The Mayer-Rokitansky-KusterHauser syndrome. Ann Intern Med 1976, 85:224-236.

2. Varner RE, Younger JB, Blackwell RE: Mullerian dysgenesis. J Reprod Med 1985, 30:443-450.

3. Folch M, Pigem I, Konje JC: Mullerian agenesis: etiology, diagnosis, and management. Obstet Gynecol Surv 2000, 55:644-649.

4. Fraser IS, Baird DT, Hobson BM, Michie EA, Hunter W: Cyclical ovarian function in women with congenital absence of the uterus and vagina. J Clin Endocrinol Metab 1973, 36:634-637.

5. Shane JM, Wilson EA, Schiff I, Naftolin F: A preliminary report on gonadotropin responsivity in the Rokitansky-Kuster-Hauser syndrome (congenitally absent uterus). Am J Obstet Gynecol 1977, I 27:326-327.

6. Azoury RS, Jones HWJ: Cytogenetic findings in patients with congenital absence of the vagina. Am J Obstet Gynecol 1966, 94:178-180.

7. Sarto GE: Cytogenetics of fifty patients with primary amenorrhea. Am J Obstet Gynecol 1974, I 19:14-23.

8. Duncan PA, Shapiro LR, Stangel JJ, Klein RM, Addonizio JC: The MURCS association: Mullerian duct aplasia, renal aplasia, and cervicothoracic somite dysplasia. IJ Pediatr 1979, 95:399-402.

9. Simpson JL: Genetics of the female reproductive ducts. Am J Med Genet 1999, 89:224-239.

10. Kobayashi A, Behringer RR: Developmental genetics of the female reproductive tract in mammals. Nat Rev Genet 2003, 4:969-980.

II. Goodman FR: Congenital abnormalities of body patterning: embryology revisited. Lancet 2003, 362:65I-662.

12. Guerrier D, Mouchel T, Pasquier L, Pellerin I: The Mayer-Rokitansky-Kuster-Hauser syndrome (congenital absence of uterus and vagina)--phenotypic manifestations and genetic approaches. J Negat Results Biomed 2006, 5:I.

13. Hombria JC, Lovegrove B: Beyond homeosis--HOX function in morphogenesis and organogenesis. Differentiation 2003, 71:46I-476.

14. Stein S, Fritsch R, Lemaire L, Kessel M: Checklist: vertebrate homeobox genes. Mech Dev 1996, 55:91-108.

15. Naora H, Montz FJ, Chai CY, Roden RB: Aberrant expression of homeobox gene HOXA7 is associated with mullerian-like differentiation of epithelial ovarian tumors and the generation of a specific autologous antibody response. Proc Natl Acad Sci U S A 200I, 98:15209-152I4.

16. Taylor HS, Vanden Heuvel GB, Igarashi P: A conserved Hox axis in the mouse and human female reproductive system: late establishment and persistent adult expression of the Hoxa cluster genes. Biol Reprod 1997, 57:1338-1345.

17. Dolle P, Izpisua-Belmonte JC, Brown JM, Tickle C, Duboule D: HOX4 genes and the morphogenesis of mammalian genitalia. Genes Dev 199|, 5:1767-1767.

18. Satokata I, Benson G, Maas R: Sexually dimorphic sterility phenotypes in Hoxa I 0-deficient mice. Nature 1995, 374:460-463.

19. Gendron RL, Paradis H, Hsieh-Li HM, Lee DW, Potter SS, Markoff E: Abnormal uterine stromal and glandular function associated with maternal reproductive defects in Hoxa-I I null mice. Biol Reprod 1997, 56:1097-I 105.

20. Warot X, Fromental-Ramain C, Fraulob V, Chambon P, Dolle P: Gene dosage-dependent effects of the Hoxa- 13 and Hoxd-13 mutations on morphogenesis of the terminal parts of the digestive and urogenital tracts. Development 1997, 124:478I-479I.

21. Patterson LT, Potter SS: Hox genes and kidney patterning. Curr Opin Nephrol Hypertens 2003, 1 2:19-23.

22. Wellik DM, Capecchi MR: Hox IO and Hox I I genes are required to globally pattern the mammalian skeleton. Science 2003, 301:363-367.

23. McGinnis W, Krumlauf $R$ : Homeobox genes and axial patterning. Cell 1992, 68:283-302.

24. Burglin TR: Analysis of TALE superclass homeobox genes (MEIS, PBC, KNOX, Iroquois, TGIF) reveals a novel domain conserved between plants and animals. Nucleic Acids Res 1997 , 25:4I73-4I80.

25. Berthelsen J, Kilstrup-Nielsen C, Blasi F, Mavilio F, Zappavigna V: The subcellular localization of PBXI and EXD proteins depends 
on nuclear import and export signals and is modulated by association with PREPI and HTH. Genes Dev 1999, I3:946-953.

26. Ferretti E, Schulz H, Talarico D, Blasi F, Berthelsen J: The PBX-regulating protein PREPI is present in different PBX-complexed forms in mouse. Mech Dev 1999, 83:53-64.

27. Selleri L, Depew MJ, Jacobs Y, Chanda SK, Tsang KY, Cheah KS, Rubenstein JL, O'Gorman S, Cleary ML: Requirement for PbxI in skeletal patterning and programming chondrocyte proliferation and differentiation. Development 200I, I 28:3543-3557.

28. Schnabel CA, Godin RE, Cleary ML: PbxI regulates nephrogenesis and ureteric branching in the developing kidney. Dev Biol 2003, 254:262-276.

29. Schnabel CA, Selleri L, Cleary ML: PbxI is essential for adrenal development and urogenital differentiation. Genesis 2003 37:123-130.

30. Schnabel CA, Selleri L, Jacobs Y, Warnke R, Cleary ML: Expression of Pbxlb during mammalian organogenesis. Mech Dev 200I, I00: |3|-|35.

31. Akarsu AN, Stoilov I, Yilmaz E, Sayli BS, Sarfarazi M: Genomic structure of HOXDI 3 gene: a nine polyalanine duplication causes synpolydactyly in two unrelated families. Hum Mol Genet 1996 5:945-952

32. Caronia G, Goodman FR, McKeown CM, Scambler PJ, Zappavigna V: An I47L substitution in the HOXDI3 homeodomain causes a novel human limb malformation by producing a selective loss of function. Development 2003, 130:170I-17/2.

33. Fedele L, Busacca M, Candiani M, Vignali M: Laparoscopic creation of a neovagina in Mayer-Rokitansky-Kuster-Hauser syndrome by modification of Vecchietti's operation. Am J Obstet Gynecol 1994, 171:268-269.

34. Louis-Sylvestre C, Haddad B, Paniel BJ: Creation of a sigmoid neovagina: technique and results in 16 cases. Eur J Obstet Gynecol Reprod Biol 1997, 75:225-229.

35. Tiker F, Yildirim SV, Barutcu O, Bagis T: Familial mullerian agenesis. Turk J Pediatr 2000, 42:322-324.

36. Miller SA, Dykes DD, Polesky HF: A simple salting out procedure for extracting DNA from human nucleated cells. Nucleic Acids Res 1988, 16:1215.

37. Devriendt K, Jaeken J, Matthijs G, Van Esch H, Debeer P, Gewillig M, Fryns JP: Haploinsufficiency of the HOXA gene cluster, in a patient with hand-foot-genital syndrome, velopharyngea insufficiency, and persistent patent Ductus botalli. Am J Hum Genet 1999, 65:249-25I.

38. Marshall H, Nonchev S, Sham MH, Muchamore I, Lumsden A, Krumlauf $R$ : Retinoic acid alters hindbrain Hox code and induces transformation of rhombomeres $2 / 3$ into a $4 / 5$ identity. Nature 1992, 360:737-74I.

39. Dubrulle J, McGrew MJ, Pourquie O: FGF signaling controls somite boundary position and regulates segmentation clock control of spatiotemporal Hox gene activation. Cell 200I, 106:219-232.

40. Goldfarb M: Functions of fibroblast growth factors in vertebrate development. Cytokine Growth Factor Rev 1996, 7:3 I I-325.

4I. Miller C, Pavlova A, Sassoon DA: Differential expression patterns of Wnt genes in the murine female reproductive tract during development and the estrous cycle. Mech Dev 1998 76:91-99.

42. Gould A, Morrison A, Sproat G, White RA, Krumlauf R: Positive cross-regulation and enhancer sharing: two mechanisms for specifying overlapping Hox expression patterns. Genes Dev 1997, II:900-913.

43. Nonchev S, Maconochie M, Gould A, Morrison A, Krumlauf R Cross-regulatory interactions between Hox genes and the control of segmental expression in the vertebrate central nervous system. Cold Spring Harb Symp Quant Biol 1997, 62:313-323.

44. Hooiveld $M H$, Morgan $R$, in der Rieden $P$, Houtzager E, Pannese $M$ Damen K, Boncinelli E, Durston AJ: Novel interactions between vertebrate Hox genes. Int I Dev Biol 1999, 43:665-674.

45. Sham MH, Hunt P, Nonchev S, Papalopulu N, Graham A, Boncinelli E, Krumlauf R: Analysis of the murine Hox-2.7 gene: conserved alternative transcripts with differential distributions in the nervous system and the potential for shared regulatory regions. Embo J 1992, II:1825-1836.

46. Benson GV, Nguyen TH, Maas RL: The expression pattern of the murine Hoxa-10 gene and the sequence recognition of its homeodomain reveal specific properties of Abdominal Blike genes. Mol Cell Biol 1995, 15:159I-160I.

47. Ventruto V, Pisciotta R, Renda S, Festa B, Rinaldi MM, Stabile M, Cavaliere ML, Esposito M: Multiple skeletal familial abnormalities associated with balanced reciprocal translocation 2;8(q32;p I3). Am J Med Genet 1983, 16:589-594.

48. Innis JW Goodman FR, Bacchelli C, Williams TM, Mortlock DP, Sateesh P, Scambler PJ, McKinnon W, Guttmacher AE: A HOXA 13 allele with a missense mutation in the homeobox and a dinucleotide deletion in the promoter underlies Guttmacher syndrome. Hum Mutat 2002, 19:573-574.

49. Min W, Cho M, Jang SI, Chang $\mathrm{HH}$, Lee CS, Jun $\mathrm{MH}$, Kim $\mathrm{MH}$ Sequence and functional analysis of an upstream regulatory region of human HOXA7 gene. Gene 1996, 182: I-6.

50. Fujimoto S, Araki K, Chisaka O, Araki M, Takagi K, Yamamura K Analysis of the murine Hoxa-9 cDNA: an alternatively spliced transcript encodes a truncated protein lacking the homeodomain. Gene 1998, 209:77-85.

51. Dintilhac A, Bihan R, Guerrier D, Deschamps S, Pellerin I: A conserved non-homeodomain Hoxa9 isoform interacting with CBP is co-expressed with the 'typical' Hoxa9 protein during embryogenesis. Gene Expr Patterns 2004, 4:2 I 5-222.

52. Guerrier D, Tran D, Vanderwinden JM, Hideux S, Van Outryve L, Legeai L, Bouchard M, Van Vliet G, De Laet MH, Picard JY, et al.: The persistent Mullerian duct syndrome: a molecular approach. J Clin Endocrinol Metab 1989, 68:46-52.

53. Knebelmann B, Boussin L, Guerrier D, Legeai L, Kahn A, Josso N, Picard JY: Anti-Mullerian hormone Bruxelles: a nonsense mutation associated with the persistent Mullerian duct syndrome. Proc Natl Acad Sci U S A 1991, 88:3767-3771.

54. Imbeaud S, Faure E, Lamarre I, Mattei MG, di Clemente N, Tizard R, Carre-Eusebe D, Belville C, Tragethon L, Tonkin C, Nelson J, McAuliffe M, Bidart JM, Lababidi A, Josso N, Cate RL, Picard JY: Insensitivity to anti-mullerian hormone due to a mutation in the human anti-mullerian hormone receptor. Nat Genet 1995, I I:382-388.

55. Muragaki Y, Mundlos S, Upton J, Olsen BR: Altered growth and branching patterns in synpolydactyly caused by mutations in HOXDI3. Science 1996, 272:548-55I.

56. Mortlock DP, Innis JW: Mutation of HOXAI 3 in hand-foot-genital syndrome. Nat Genet 1997, 15:179-180.
Publish with Biomed Central and every scientist can read your work free of charge

"BioMed Central will be the most significant development for disseminating the results of biomedical research in our lifetime. "

Sir Paul Nurse, Cancer Research UK

Your research papers will be:

- available free of charge to the entire biomedical community

- peer reviewed and published immediately upon acceptance

- cited in PubMed and archived on PubMed Central

- yours - you keep the copyright
BioMedcentral 